\title{
LHUILLERY, Stéphane \\ In search of lost disincentive effects from intra-industry spillovers
}

\author{
Chaire en Economie et Management de l'Innovation - CEMI, \\ CDM Working Papers Series - March 2009
}

CEMI-WORKINGPAPER-2009-005

Keywords : intra-industry spillovers, absorption, innovation survey

JEL classification : $\mathrm{O} 31, \mathrm{C} 35, \mathrm{C} 81$

\begin{abstract}
Standard innovation surveys do not consider incoming spillovers for non-innovative firms. The Swiss innovation surveys presented here measure the importance of competitors' knowledge for both innovating and noninnovating firms. This original feature not only enables us to accurately identify the role of incoming knowledge on $R \& D$ decisions and innovation output, but also to compare resulting data with those which standard innovation questionnaires provide. Using a panel data over four periods, we show that knowledge from rivals actually deters manufacturing firms from engaging in R\&D activities. Moreover, we provide stronger evidence that intra-industry spillovers are more detrimental to innovation than that generally provided by data from standard surveys. The results suggest that the dominance of the absorptive capacity effect is more important to firms investing in R\&D and that non-innovative firms rely more heavily than expected on their competitors to maintain their technological capacities.
\end{abstract}




\section{Acknowledgement}

We gratefully acknowledge Spyros Arvanitis, Heinz Hollenstein and Martin Wörter (KOF, ETHZ, Zurich) for providing the prepared panel data as well as for sharing their tacit knowledge of this dataset, the participants at the "Science and Technology Research In a Knowledge-based Economy" (STRIKE) conference in KU Leuven, Belgium October $18^{\text {th }}-20^{\text {th }}$ 2007, Stephane Robin (BETA, Strasbourg) and the participants at the "Innovation seminar" at the Ministry of Industry, March $4^{\text {th }} 2008$. Usual disclaimers apply. 


\section{Introduction}

Ever since the seminal article by Arrow (1962), many theoretical models using a symmetric view of knowledge spillovers (e.g. Spence 1984) have advocated that R\&D efforts decrease with knowledge spillovers. A symmetric view of spillovers is usually implemented where no technological hierarchy among firms is supposed: in this case, outgoing knowledge spillovers dissuade a firm from investing in R\&D (disincentive effect) whereas incoming knowledge spillovers encourage firms to reduce their own production of knowledge by free-riding other firms (efficiency effect). When an asymmetric view of knowledge spillovers among competitors is adopted, "technological leaders have less to learn from others than followers do" (Eeckout and Jovanovitch 2002). An increase in knowledge spillovers from leaders to followers tends to have the usual discouraging effect on competing leaders but also induces a decrease in followers' R\&D investment when one-way outgoing spillovers from leaders to followers are high and spillovers among competing leaders are low (Vandekerckhove and De Bondt 2008). In such a framework, it is interesting to note that lagging firms can choose to be pure imitators (See also Nelson and Winter 1982).

This disincentive effect was seriously challenged by Cohen and Levinthal (1989), when they suggested that R\&D investment can be seen as a strategic complement instead of a strategic substitute for firms: the deterring effect arising from knowledge spillovers may be dominated by the R\&D efforts required to build an absorptive capacity, consequently enabling firms to capture external knowledge, including rivals' knowledge. This persuasive argument is also in line with certain econometric studies which reported that firms benefiting from external knowledge were the same ones investing most in R\&D (Jaffe, 1986; Levin, 1988). However, the importance of absorptive capacity over the disincentive effect for intra-industry spillovers has not been seriously tested. Despite the lack of empirical evidence regarding this issue, there is a widespread and persistent conviction that learning costs are dominant while disincentive effects are not very important. This viewpoint has been maintained by many recent empirical works based on innovation surveys (e.g. Community innovation surveys, CIS hereafter) where incoming knowledge is directly assessed through Likert scales.

The present paper proposes to focus on the lack of attention given to the disincentive effect in empirical literature based on innovation questionnaires. The fact that standard innovation questionnaires assess incoming knowledge (in particular, knowledge coming from rivals) only for "innovative" firms has important consequences for the ability to identify their effects on R\&D or innovation outputs. Employing a sub-sample restricted to innovative firms, using censored regressors and the introduction of a selection equation are some of the answers which have been proposed by scholars to correct this problem. We argue however that these solutions, implemented in order to cope with selectivity, not only fail to provide accurate identification of spillover parameters but also fail to unveil the strength of the disincentive effect of rivals' ideas on innovative inputs and outputs.

In order to test this proposal, we use the Swiss innovation panel data (KOF - ETH Zürich) composed of 1,744 manufacturing firms over four periods (1993-1995, 1996-1998, 1999-2001, 2002-2003) or 2,653 firm-years to measure not only the importance of incoming external knowledge for innovators (as many innovation surveys do) but also that for non-innovators. 
First, all data are implemented using a structural model similar to that used by Crépon et al. (1989), thereby facilitating the exploration of the "real" impact of rivals' knowledge, either on $\mathrm{R} \& \mathrm{D}$ decisions or on innovative output. We then assess the different solutions proposed by scholars, restricting our use of Swiss data to that which a standard CIS questionnaire would generally offer.

The remainder of the paper is organized as follows. Section 2 briefly surveys the empirical literature on the impact of knowledge spillovers from rivals on R\&D and innovation. Section 3 describes the data collected and section 4 presents the econometric methodology. Results are presented in the next section. The final section deals with our conclusions.

\section{Empirical background}

The literature provides three different implemented methods regarding the identification of the disincentive effect of competitors' incoming knowledge on R\&D or innovation. In the first method, scholars try to identify, directly through questionnaires, those firms which are imitators or laggards. The asymmetric view of spillovers employs the idea that laggards benefit more from leaders and thus need to invest less in R\&D. Using this concept, Link and Neufeld (1986) confirmed that imitators are less R\&D intensive than innovators.

The second method does not introduce any differences between firms, considering that each firm supplies all its rivals with knowledge through outgoing spillovers and that the latter supply the former in a reciprocal fashion. In this framework, an external pool of knowledge is computed, in order to assess if there is a negative impact of the potential incoming knowledge spillovers on R\&D investment. Bernstein and Nadiri (1989) found a disincentive effect. The robustness of this result has however been challenged by several papers: Boone et al. (2007) suggest for example that the disincentive effect of competitors' $R \& D$ is not robust when strategic externalities are controlled for. Jaffe (1986) reports that the R\&D pool positively affects the number of patents filed but also that R\&D intensity and the intra-industry R\&D pool are complementary.

The third method stems from the emergence in the 1980s of a qualitative and direct measurement of the role of incoming knowledge in the innovation process (see Levin et al., 1987; OECD, 1992). Adopted by different innovation surveys ${ }^{1}$ ever since 1992, in this approach the question asked on incoming knowledge is for example: "Please indicate the sources of knowledge or information used in your technological innovation activities, and their importance during the period 1998-2000" (from UK CIS3), where answers are given for each type of external source (parent firms, customers, suppliers, competitors, universities, consultants) and are ranked according to their degree of importance (Not used, Low, Medium, High). In these standardized CIS questionnaires, incoming spillover variables are observed only for the sub-set of innovative firms. Yet, incoming knowledge is also important for non-innovating firms in order to maintain their technological capacities. Technological capacities of non-innovative firms may be not high enough to generate genuine innovation or significant improvements in processes or products but are still very important in maintaining high performance within a firm which uses almost the same processes and products (learning curves) or which may want to keep the opportunity to innovate in the future open (option value) (Kogut and Kulatilaka, 1994).

\footnotetext{
${ }^{1}$ Community innovation surveys and also numerous innovation surveys carried out in developing countries based sometime on the "Bogota Manual” (See Raffo et al., 2008 for main references).
} 
A selection problem therefore exists in the direct measurement of incoming spillovers and three different solutions to this question can be found in the academic literature. The first, which is also the most popular among scholars, proposes reducing the analysis to the sub-sample of innovative firms. In this setting, Crespi et al., (2007), show that knowledge coming from competitors does not influence the number of patents declared by U.K. innovating firms. Similarly, Belderbos et al. (2004) report that incoming competitors' ideas do not influence the evolution of innovative sales per employee. In contrast to this however, when innovation inputs are considered, Cassiman and Veugelers (2006) show on a restricted sample of Belgium firms that rivals' ideas induce firms to invest less in $R \& D$, subcontract it to a greater extent or buy it all outright.

The second solution, initiated by Crépon, Duguet and Mairesse (1989) analyses R\&D decisions and innovation determinants on the whole sample of firms, including non-innovators. In this case, variables on incoming knowledge need to be censored in order to be introduced in R\&D or innovation output equations (Lööf and Heshmati, 2002; Griffith et al. 2006; Raffo et al., 2008). The different authors assume that non-innovating firms do not benefit from external sources of technological knowledge and consequently incoming knowledge is forced to the minimum value of the Likert scale (i.e. it is not important). Along these lines, Griffith et al. (2006) found there is a positive impact of spillovers from rivals on the likelihood of being a product or process innovator for firms in France and Spain, whereas non-significant coefficients are found for firms Germany and the United Kingdom. The heterogeneity of these results is confirmed by Raffo et al. (2008) who find a positive coefficient for Swiss firms in terms of process innovation but a non-significant relationship for French firms. Regarding the R\&D intensity equation, Raffo et al. (2008) do not find any significant effect of rivals' knowledge for Swiss firms but instead report a positive one for France firms, suggesting a dominant absorption capacity effect over the disincentive effect ${ }^{2}$.

The third solution to the selectivity problem is, of course, to introduce a selection equation in order to correct the previous method for possible selection bias. In this way, the innovation output equation is still restricted to the sub-sample of innovative firms but takes the problem of sample selectivity into account (Lööf and Heshmati, 2002). Using censored regressors and correcting for selectivity, Lööf and Heshmati (2002) also find a positive effect of competitors' knowledge on innovative sales, both in terms of level and growth-rate.

All three methods are laudable efforts to overcome the selectivity problem regarding incoming knowledge variables. We contend however that they do not provide accurate identification of the role of rivals' ideas, either in terms of innovation input or innovation output. The likelihood of innovating or not, and the decision to invest in R\&D or not are both influenced by incoming spillovers influencing all firms, including non-innovative ones. To restrict the analysis to innovative firms is to neglect potential selection biases. The introduction of a selection equation may not properly correct for these biases since incoming knowledge certainly influences the selection process. The use of censored regressors, as carried out by Griffith et al. (2006) is an interesting solution but may induce upward biases (Rigobon and Stoker 2007).

The next sections assess the role of incoming spillovers, especially from competitors, on R\&D decisions and innovation outcomes by implementing uncensored data. First, the real impact of incoming spillovers is evaluated. The results from this are then used as a benchmark in order to compare the results that would be obtained with data coming from a standard innovation questionnaire.

\footnotetext{
${ }^{2}$ The external sources are successfully introduced into the R\&D intensity equation by Griffith et al. (2006) but the coefficients are not reported by the authors.
} 


\section{Data and variables}

The data used in this study comes from the 1996, 1999, 2002 and 2005 Swiss innovation surveys administrated by the KOF. The four waves of the Swiss questionnaire are similar to the Community Innovation Survey (CIS) questionnaire examining the nature and impact of innovation in the business sector at the European Union level and draws extensively on the Oslo manual's guidelines (OECD, 1992). The data include measures of innovation-related expenditure, factors which have either encouraged or hampered innovation, including property rights, and the innovation outcome.

As already suggested, the KOF questionnaires (1996, 1998, 2002, 2005) depart from other standard innovation questionnaires (e.g. from CIS1 to CIS4), exploring the source of external technological information and knowledge for innovative and non-innovative firms. The Swiss questionnaire uses the same method to directly measure incoming knowledge but is more general, asking the question «What is the importance of external sources of knowledge external to your firm for your own capacity of innovation" and rating the replies on a five-point Likert item. Non-innovating firms are thus asked to answer the question following the assumption that such firms have in fact their own "capacity of innovation", something which is not taken into account in standard questionnaires.

Beyond the incoming knowledge per type of external source (BUSINESS GROUP, SUPPLIER, COMPETITOR, CUSTOMER, UNIVERSITY, CONSULTANT), the other variables available are very similar to those of the CIS, as reported in Table 1 . The Swiss innovation panel data covers innovation inputs (R\&DYES, R\&DI, R\&D COOP), efficiency of appropriation strategies (APPROPRIATION), and innovation output (PRODUCT, PROCESS). As Table 1 also reports, the Swiss questionnaire includes additional general questions providing control variables (size, industry, price and non-price competition, perceived number of competitors, technology potential and demand anticipated). Note that the perceived number of competitors is an original variable and enables capturing data on potential or foreign competitors.

\section{INSERT TABLE 1 ABOUT HERE}

The Swiss innovation panel is a collection of four innovation surveys among Swiss firms for the years 1996, 1999, 2002 and 2005. These surveys were based on stratified random samples of firms with at least 5 employees covering all manufacturing industries and some services (see Arvanitis, 2008). The KOF survey is a voluntary mail survey with response rates for the covered manufacturing firms as follows: 33.5\% (1996), 33.7\% (1999), 44.6\% (2002) and 38.7\% (2005). Our final data, restricted to the manufacturing industry, omitting all firm-years with missing values, firms with less than 5 employees and firms with more than $50 \%$ of their activity spent in R\&D, is an unbalanced panel of 2,653 firm-years (680, 633, 890, 450 for the years 1996, 1999, 2002, 2005 respectively) for 1,744 firms distributed over the four periods, and may be considered as representative of Swiss manufacturing industry ${ }^{3}$.

\footnotetext{
${ }^{3}$ In the paper, we do not use imputed values for the different variables and the number of firm-years available is thus reduced. The final sample is unbalanced: out of the 1,744 firms, 1082 were present during one period, 453 during two periods, 165 during three periods and only 41 during all four periods.
} 
We now propose an empirical model which will serve as a guideline to compare the results obtained with two of the different possible solutions proposed in the literature and outlined above.

\section{Econometric modeling}

In order to evaluate the differences between the usual solutions and that facilitated by the Swiss data, we propose using an integrative framework developed by Crépon, Duguet and Mairesse (1989) (CDM thereafter). The full CDM model includes the following three relationships and interactions: innovation input to its determinants; innovation output to its inputs; productivity explained by innovation. Only the first two relationships are considered in the present paper, using covariates comparable to Griffith et al.'s (2006).

This paper proposes an original extension of the cross sectional CDM model into a four period panel data (1993-1995, 1996-1998, 1999-2001, 2002-2004). This extension is however difficult for the first equation exploring the likelihood of being R\&D active, since two thirds of firms are stable R\&D investors or non R\&D investors and so the interest in using a panel probit model with fixed effects (FE hereafter) is greatly reduced. In order to overcome this difficulty, we propose estimating a sample selection model with random effects (RE) as follows:

$$
\left\{\begin{aligned}
R \& D Y E S_{i t}^{*} & =\kappa_{1}{ }^{\prime} \text { COMPETITOR }+\chi_{1}{ }^{\prime} s_{1 i t}+\delta^{\prime} \mathrm{w}_{\mathrm{it}}+u_{1 \mathrm{i}}+\varepsilon_{1 \mathrm{it}} \\
R \& D I_{i t}^{*} & =\underset{<0}{\kappa_{2}{ }^{\prime} \text { COMPETITOR }+\chi_{2}{ }^{\prime} s_{2 i t}+\beta^{\prime} \mathrm{x}_{\mathrm{it}}+u_{2 \mathrm{i}}+\varepsilon_{2 \mathrm{it}}}
\end{aligned}\right.
$$

where R\&DYES is the observed binary variable equal to 0 for non-R\&D firms and 1 for firms reporting enough positive internal $R \& D$, and where a negative coefficient is expected for the COMPETITOR variable $\left(\kappa_{1}<0\right.$ in subscript). $\mathbf{s}$ is the matrix for other external sources of knowledge. $\mathbf{w}$ is a matrix for other variables including APPROPRIATION where a positive sign is expected ${ }^{4}$. Appropriation controls for the ability of firms to control outgoing spillovers and is thus the second face of the issue of incoming knowledge which we are focusing on. Other variables are control variables such as size, perceived number of competitors, type of competition, technological potential and anticipated demand explaining R\&D decisions. $\chi_{1}$ and $\delta$ are vectors of parameters of interest to be estimated, $\mathbf{u}_{1}$ a firm specific random term and $\varepsilon_{1}$ an error term.

Conditional on firm i reporting systematic R\&D, the declared intensity R\&DI of the latent variable R\&DI* is then observed and explained when R\&DYES is 1 . In the R\&D intensity equation, if the disincentive effect prevails over the absorptive capacity effect, the coefficient of COMPETITOR is also expected to be negative $\left(\kappa_{\mathbf{2}}<0\right) . \mathbf{s}_{\mathbf{2}}$ and $\mathbf{x}$ are matrixes of variables explaining R\&D intensity. $\mathbf{s}_{\mathbf{2}}$ is defined as above; compared with $\mathbf{w}$, the $\mathbf{x}$ matrix includes an additional variable: an R\&D cooperation dummy (R\&D COOP). The introduction of this latter is carried out in order to control for the differences between internalized and non-internalized incoming spillovers (See Belderbos et al. 2004 on this problem). $\chi_{2}$ and $\beta$ are vectors of

\footnotetext{
${ }^{4}$ The PUBLIC FUNDING variable has been included in KOF questionnaires only since the 1999 version. In order to keep our four periods instead of only three, we do not introduce the variable which is endogenous and in any case concerns very few companies in Switzerland.
} 
parameters of interest to be estimated. $\mathbf{u}_{2}$ is a firm specific random term and $\varepsilon_{2}$ an error term. The same four periods are considered ${ }^{5}$.

The innovation stage is usually modeled as follows in CDM models:

$$
\mathrm{INNO}_{\mathrm{it}}^{*}=\kappa_{<0}{ }^{\prime} \text { COMPETITOR }+\chi_{3}{ }^{\prime} s_{3 i t}+\gamma^{\prime} \mathrm{R}^{\prime} \& \mathrm{DI}_{\mathrm{it}}^{\mathrm{PRED}}+\mu^{\prime} \mathrm{z}_{\mathrm{it}}+u_{3 \mathrm{i}}+\varepsilon_{3 \mathrm{it}}
$$

where $I N N O_{i t}$ are the different possible knowledge outputs, influenced by R\&D intensity. The integration of the model usually relies on the introduction in equation (3) of the linear predicted value of R\&DI, R\&DI ${ }^{\mathrm{PRED}}$, instead of the observed R\&DI in order to take the endogeneity of $\mathrm{R} \& \mathrm{DI}$ into account. R\&D cooperation and knowledge from universities are considered here as instruments.

Controlling for endogeneity in panel data with non-linear variables is however very difficult. In order to overcome this problem we propose modifying the standard equation (3), replacing the R\&DI variable with the R\&DYES variable. Doing this, we define a bivariate model with recursivity and random effects (See Sickles and Taubman (1986), Geoffard and Lamiraud (2007) for previous use). The bivariate model with random effects is then:

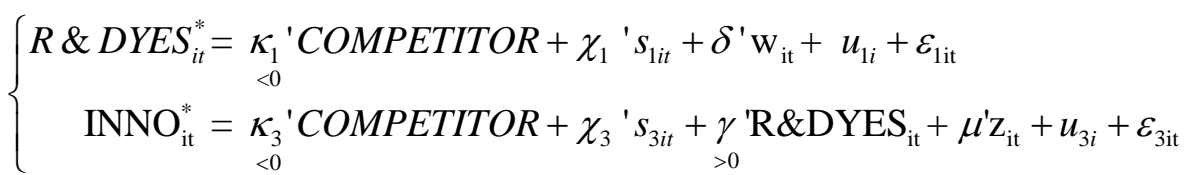

where the variables in the R\&DYES equation are the same as for equation (1) above. In the second equation, a dominant deterring effect from incoming rivals' knowledge should lead to a negative effect on innovation output $\left(\kappa_{3}<0\right)$. Similar to Griffith et al. (2006), innovation output is also determined by knowledge spillovers $\left(\mathbf{s}_{\mathbf{3}}\right)$ coming from suppliers, customers and parent firms, as well as by other determinants of knowledge production, $\mathbf{z} . \chi_{3}, \gamma$ and $\mu$ are parameters of interest, $\mathbf{u}_{3}$ is a firm specific random term, $\boldsymbol{\varepsilon}_{3}$ an error term and $\mathbf{t}$ the four periods considered. In such a recursive bivariate model, the endogeneity of a dichotomic variable can be controlled for. Product innovation (PRODUCT) and process innovation (PROCESS) are thus preferred as innovation output variables (INNO). In the bivariate models, the endogeneity of R\&DYES is taken into account using the variable on academic knowledge sourcing as an instrument.

Using this framework, we first present the "true" model for all Swiss firms, both innovative and non-innovative, which use incoming knowledge spillovers. Using Griffith et al.'s (2006) interesting idea, a second set of specifications then proposes to introduce censored regressors, considering that external knowledge is not important to non-innovative firms. In a formal way, the COMPETITOR $\mathrm{it}_{\mathrm{it}}^{\text {censored }}$ variable is, as for the other external source variables, defined as

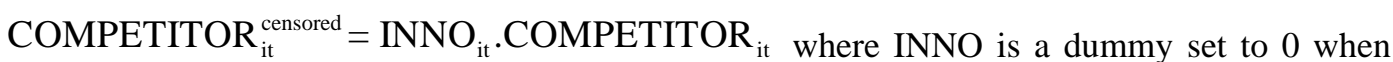
the firm declares itself as non-innovative. The censored variables are thus introduced in place of

\footnotetext{
${ }^{5}$ Note that a Simple Tobit model with fixed effects can be implemented for equation (2). The use of a fixed effect Tobit model for panel data is however a problem because of the restricted number of periods (See Greene, 2006). The simple Tobit results with RE or FE are available upon request.
} 
uncensored variables in equations (2) and (3). Finally, a third set of regressions implements equations (1) and (2) specifically for innovative firms ${ }^{6}$ only.

\section{Results}

Descriptive statistics are reported in Table 2. In our sample, around $78 \%$ of firm-years are innovative and $58 \%$ of these declare some kind of positive R\&D profile. $26 \%$ of innovative firms cooperate with other firms in R\&D. Unsurprisingly, non-innovative firms are smaller than innovative ones and these perceive fewer competitors than the former. They also declare more often that they compete on non-price basis ( $46 \%$ vs $27 \%$ ). More interesting is the importance of incoming spillovers for non-innovative firms who benefit to a great extent from external knowledge but in a less systematic way, especially in terms of knowledge coming from parent firms, clients, universities or consultants. Non-innovating firms depend more on their competitors (41\%) or suppliers (29\%) to maintain their technological capacities than innovative firms (33\% and 22\% respectively) or even firms carrying out R\&D (34\% and $21 \%$ respectively).

\section{INSERT TABLE 2 ABOUT HERE}

As Table 3 reports, the level of R\&D investment is not significantly influenced by external knowledge: firms increase their R\&D investment in order to capture academic knowledge and decrease such investment when they benefit from their own business group knowledge. The results on R\&D intensity are robust whatever the specification chosen (compare [2a], [2b] and [2c]). However, the important role of competitors is unveiled when rivals' knowledge is introduced into equation [1]. As column [1a] reveals, when a firm benefits from its rivals' knowledge, the likelihood of it investing in R\&D diminishes. This result is new, as existing literature usually introduces external knowledge only in the R\&D intensity equation (see [1b]) or limits the investigation to innovative firms (see [1c]).

A similar conclusion is reached for knowledge coming from suppliers: the disincentive effect is in fact much stronger than a CIS based study would suggest. Our results confirm the positive role of customers' knowledge on R\&D decisions (Column [1a] or column [2a]). Similarly, the existence of a dominant absorptive capacity effect is preserved with respect to the role of universities as sources of knowledge (Column [1a] to [2c]).

The results confirm that standard studies based on direct measure of incoming knowledge understate the importance of the disincentive effect of intra-sectoral spillovers on R\&D. Missing the fact that rivals' ideas provide the opportunity to NOT invest in R\&D, scholars overestimate the absorptive capacity effect, which may be important only for firms investing in R\&D.

\section{INSERT TABLE 3 ABOUT HERE}

\footnotetext{
${ }^{6}$ A correction for selectivity à la Lööf and Heshmati (2002) in equation (3) is not easy in panel data framework where the endogeneity of R\&D is a priority problem to deal with. This third solution we outlined in section 2 is thus not implemented in the present paper.
} 
This disincentive effect of rivals' knowledge is also found to be usually understated as the results on innovation output equation [3] show (See Table 4). The results obtained with uncensored variables describe a disincentive effect of rivals' knowledge on the likelihood of being product innovative [3a] whereas the coefficient is not found to be significant for process innovation [3b]. As columns [3c] and [3d] report, the use of censored regressors à la Griffith et al. (2006) provides a very different result revealing positive coefficients synonym of an upward biased on external knowledge coefficients. Incoming intra-industry spillovers are thus shown to be more detrimental in our study than in standard ones. This result is in line with the foregoing results we obtained for $R \& D$ : intra-industry incoming spillovers deter $R \& D$ activity and, consequently, reduce innovative outputs. It also suggests that non-innovating firms are capable of tapping knowledge from other firms to a greater extent than one would have expected from current absorptive capacity literature.

\section{INSERT TABLE 4 ABOUT HERE}

The different results support our hypothesis that questionnaires focusing solely on innovative firms induce significant difficulties for scholars when trying to identify the real effect of spillovers. Moreover, they especially undervalue the disincentive impact of competitors' knowledge on R\&D decisions and innovation outcomes. The present paper also confirms some other hypotheses usually found in the literature.

For instance, $R \& D$ co-operation is found to positively influence $R \& D$ intensity [2a]. Large firms are more likely to be involved in R\&D activities [1a] or to be $R \& D$ intensive [1b] ${ }^{7}$ than SMEs. As expected, larger firms and firms with $R \& D$ activities are also more likely to be product or process innovators (see [3a], [3b]).

Appropriation is found to be, as expected, positively related to the decision to invest in R\&D (See Table 3, [1a]). However this positive effect vanishes for R\&D intensity ([2a]). The capacity of appropriation is also positively linked to process innovation [3b] but surprisingly not for product innovation, as described in column [3a] of Table 4. One interpretation for this is that many non-innovators are laggards for whom it is easier to efficiently protect their know-how. These firms subsequently declare that they are able to protect their advantage whereas the same task is considered to be harder by innovators and especially technological leaders.

The perceived number of competitors is found to deter firms from being R\&D intensive ([2a]). This result is in line with the traditional idea that firms which monopolize power within their market niche are more likely to get returns from their R\&D investments. The larger the number of competitors, the higher the likelihood to innovate in processes ([3b]. The impact of competition on product innovation is however unclear (see [3a]).

Although non-price competition encourages firms to invest in R\&D ([1a]), it does not significantly foster innovation (Table 4). Firms which believe that their industry has important technology opportunities are more likely to invest in R\&D or to be R\&D intense. A growing anticipated demand is also found to be a significant determinant for $R \& D$ investment. Technological opportunities and anticipated demand are however found to be weaker determinants of innovation. The lack of results regarding this point may be due to the time lag, as the considered innovations were introduced over the last three years of the study while the two explanatory variables were oriented towards future technology or demand.

$7 \quad$ The U shaped curve reaches a minimum for 150 employees. 


\section{Conclusion}

The Swiss innovation questionnaires include an original measurement of the impact of incoming knowledge on a firm's innovation capacities: the measure is performed on innovating and noninnovative firms. The resulting data facilitates the identification of the "true" impact of incoming knowledge and especially of competitors' ideas on R\&D decisions and innovation output. It also enables us to compare these results with those usually produced with a standard innovation questionnaire. In this respect, we argue that the standard innovation questionnaire focusing on innovative firms introduces a systematic upward bias when the impact of external knowledge on R\&D or innovation is considered. More specifically, we argue that studies, based on CIS questionnaires or based only on firms with R\&D, either fail to show the importance of the disincentive effect regarding the decision to invest in $R \& D$ or overestimate the impact of rivals' knowledge on innovative activities.

The empirical results confirm our hypothesis. Unlike results which can be obtained using a common CIS questionnaire, intra-industry spillovers dissuade firms from engaging in R\&D activities. Finally, rivals' knowledge is not found to be positively linked to the introduction of product or process innovation. These results contradict the general belief that disincentive effects of incoming spillovers are usually dominated by counterbalancing learning effects large enough to create strategic complementarities among competitors.

Our results do not imply that the absorption theory does not hold anymore. They suggest that the standard absorptive capacity effect is more important for those firms carrying out R\&D or who are technological leaders. These same firms disclose knowledge thereby dissuading R\&D investment for non-R\&D investors and technological laggards. At the same time, many lagging firms are unlikely to get positive returns from their R\&D investments and are more likely to survive relying on external sources such as competitors or suppliers ${ }^{8}$.

The empirical results reinvigorate the idea that intra-industry spillovers act as a critical determinant of technological strategies. They support theoretical considerations which insist on the importance of active imitation strategies among learning competitors with asymmetric spillovers (Nelson and Winter 1982; Eeckhout and Jovanovic 2002; Vandekerckhove and De Bondt 2007) where laggards or firms without $R \& D$ learn more from other firms, especially from competitors closer to cutting-edge technological development.

To conclude, the present paper underlines the limitations of the CIS questionnaire and illustrates, through the KOF questionnaire, its possible extension toward non-innovators on questions pertaining to knowledge sourcing. The differences found between R\&D active and non-active firms also argue for a direct measurement of technology positions among competitive firms. Questionnaires could first try to tackle this difficult issue through a characterization of the imitation strategies used by firms. Our opinion is that the usual question asked in innovation questionnaires, distinguishing between an innovation "new to the firm" but "not new to the market", may identify followers but fail to identify imitators. Certain firms can consider themselves as non- innovating because they do not judge their imitation strategy as an innovative strategy. The two changes in questionnaires would facilitate the testing of theoretical models with asymmetric spillovers more precisely and would alleviate a major impediment in the understanding of patterns of industrial evolution.

\footnotetext{
${ }^{8}$ The present paper does not explain however how non-innovative firms or non-R\&D firms are able to capture external knowledge. The hypothesis that R\&D is a latent variable is an appealing but oversimplified explanation for the existence of a non-R\&D based absorptive capacity.
} 


\section{References}

Arvanitis S (2008) Innovation and labour Productivity in the Swiss Manufacturing Sector: An Analysis on Firms Panel Data. In: Van Beers C, Kleinknecht A, Ortt R, Verburg R (ed) Determinants of Innovative Behaviour: A Firm's Internal Practices and its External Environment. Palgrave Macmillan.

Bernstein JI, Nadiri MI (1989) Research and Development and Intra-industry Spillovers: An Empirical Application of Dynamic Duality. Rev. of Econ. Stud. 56(2): 249-269.

Belderbos R, Carree M, Lokshin B (2004) Cooperative R\&D and firm performance. Res. Policy 33(10): 1477-1492.

Bloom N, Schankerman M, and Van Reenen J (2007) Identifying technology spillovers and product market rivalry. NBER Working Paper No 13060.

Cassiman B, Veugelers R (2006) In Search of Complementarity in Innovation Strategy: Internal R\&D, Cooperation in R\&D and External Technology Acquisition. Manag. Sci. 52(1): 68-82.

Cohen W, Levinthal D, (1989) Innovation and Learning: The Two Faces of R\&D. The Econ. J. 99(397): 569-596.

Crépon B, Duguet E, and Mairesse J (1998) Research and Development, Innovation and Productivity: An Econometric Analysis at the Firm Level. Econ. of Inno. and New Technol. 7(2): 115-58.

Crespi G, Criscuolo C, Haskel JE, Slaughter M (2008) Productivity Growth, Knowledge Flows, and Spillovers. NBER Working Papers 13959.

Eeckhout J, Jovanovic B (2002) Knowledge Spillovers and Inequality. Am. Economic Rev. 92(5): 12901307.

Greene W (2006) Censored data and truncated distributions. In: Mills T, Patterson K (ed) Palgrave Handbook of Econometrics, Vol. 1: Theoretical Econometrics. Palgrave-Macmillan, London, pp 695-736.

Griffith R, Huergo E, Mairesse J and Peters B (2006) Innovation and Productivity Across Four European Countries. Oxf. Rev. of Econ. Policy 22(4): 483-498.

Jaffe A (1986) Technological Opportunity and Spillovers of R\&D. Am. Econ. Rev. 76: 984-1001.

Lamiraud K, Geoffard PY (2007) Therapeutic non-adherence: a rational behavior revealing patient preferences? Health Econ. 16(11): 1185-1204.

Levin RC, Klevorick AK, Nelson RR, Winter SG (1987) Appropriating the Returns from Industrial Research and Development. Brookings Pap. on Econ. Act., Economic Studies Program, The Brookings Institution 18(3): 783-832.

Levin RC (1988) Appropriability, R\&D spending, and Technological performance. Am. Econ. Rev. 78(2): 424-428.

Link AL, Neufeld JL (1986) Innovation versus imitation: investigating alternative R\&D strategies. Appl. Econ. 18(12): 1359-1363.

Lööf H, Heshmati A (2002) Knowledge capital and performance heterogeneity: A firm-level innovation study. Int. J. of Prod. Econ. 76(1): 61-85.

Nelson R, Winter S (1982) An evolutionary theory of economic change. Belknap Press, Cambridge.

OECD, (1992) Oslo Manual: Guidelines for Collecting and Interpreting Innovation Data, $1^{\text {st }}$ Edition. OECD, Paris.

Raffo J, Lhuillery S, Miotti L (2008) Northern and southern innovativity: a comparison across European and Latin American countries, Eur. J. Dev. Res. 20(2): 219-239.

Rigobon R, Stoker T (2007) Estimation with censored regressors: basic issues, Special issue in Honor of Daniel Mc Fadden. Int. Econ. Rev. 48 (4): 1441-1467.

Sickles RC, Taubman P (1986) An analysis of the health and retirement status of the elderly. Econ. 54(6): 1339 - 1356.

Spence M (1984) Cost Reduction, Competition, and Industry Performance. Econ. 52(1): 101-21.

Vandekerckhove J, De Bondt R (2008) Asymmetric spillovers and investments in research and development of leaders and followers. Econ. of Inno. and New Technol. 17(5): 417-433. 
Table 1 : Description of variables

\begin{tabular}{|c|c|}
\hline Variable name & Definition \\
\hline \multicolumn{2}{|l|}{ Dependent variables } \\
\hline R\&DYES & $\begin{array}{l}\text { Dummy variable which takes the value } 1 \text { if the enterprise reports engagement in } \\
\text { intramural } R \& D \text { and a positive } R \& D \text { budget. }\end{array}$ \\
\hline R\&DI & $\begin{array}{l}\text { Research and development investment / sales for the last year of the three year period } \\
\text { (plus the minimum of the positive value of the ratio and then taken in logarithm) }\end{array}$ \\
\hline PRODUCT & $\begin{array}{l}\text { Dummy variable which takes the value } 1 \text { if the firm reports having introduced at least } \\
\text { one new or technologically significantly improved product (new to the market or only } \\
\text { new to the firm) during the three year period. }\end{array}$ \\
\hline PROCESS & $\begin{array}{l}\text { Dummy variable which takes the value } 1 \text { if the firm reports having introduced at least } \\
\text { one new or technologically significantly improved production process during the three } \\
\text { year period. }\end{array}$ \\
\hline \multicolumn{2}{|l|}{ Explanatory variables } \\
\hline PARENT & $\begin{array}{l}\text { Dummy variable which takes the value } 1 \text { if knowledge from parent firms was important } \\
\text { or of great importance during the three year period }\end{array}$ \\
\hline CUSTOMER & $\begin{array}{l}\text { Dummy variable which takes the value } 1 \text { if knowledge from customers or clients was } \\
\text { important or of great importance during the three year period }\end{array}$ \\
\hline COMPETITOR & $\begin{array}{l}\text { Dummy variable which takes the value } 1 \text { if knowledge from competitors and other firms } \\
\text { from the same industry was important or of great importance during the three year } \\
\text { period }\end{array}$ \\
\hline SUPPLIER & $\begin{array}{l}\text { Dummy variable which takes the value } 1 \text { if knowledge from suppliers was important or } \\
\text { of great importance during the three year period }\end{array}$ \\
\hline UNIVERSITY & $\begin{array}{l}\text { Dummy variable which takes the value } 1 \text { if knowledge from universities or colleges was } \\
\text { important or of great importance during the three year period }\end{array}$ \\
\hline CONSULTANT & $\begin{array}{l}\text { Dummy variable which takes the value } 1 \text { if knowledge from consultancy firms or } \\
\text { technological transfer firms was important or of great importance during the three year } \\
\text { period }\end{array}$ \\
\hline R\&D COOP & $\begin{array}{l}\text { Dummy variable which takes the value } 1 \text { if the firm had some cooperative arrangements } \\
\text { for their R\&D activities during the three year period }\end{array}$ \\
\hline APPROPRIATION & $\begin{array}{l}\text { Dummy variable which takes the value } 1 \text { when the competitive advantages due to } \\
\text { product or process innovations are declared to be protected in to a large of very large } \\
\text { extent by IPR or non-IPR strategies (e.g. patents, trademarks trade, copyright, secrecy, } \\
\text { advantage time, product or process complexity, long-term employment of specialized } \\
\text { personnel, etc.) during the three year period. }\end{array}$ \\
\hline Size & Logarithm of the number of employees for the last year of the three year period. \\
\hline Price competition & $\begin{array}{l}\text { Dummy variable which takes the value } 1 \text { when the intensity of price competition is } \\
\text { considered as strong or very strong. }\end{array}$ \\
\hline Non Price competition & $\begin{array}{l}\text { Dummy variable which takes the value } 1 \text { when the intensity of non-price competition is } \\
\text { considered as strong or very strong. }\end{array}$ \\
\hline Perceived number of competitors & $\begin{array}{l}\text { Dummies for four different market types: more than } 50 \text { competitors in the (worldwide) } \\
\text { product market; } 16 \text { to } 50 \text { competitors; } 11 \text { to } 15 \text { competitors; } 6 \text { to } 10 \text { competitors; } \\
\text { (reference group: up to } 5 \text { competitors) }\end{array}$ \\
\hline Demand & Demand expectations over the next three years \\
\hline Technology Potential & The technological potential of the firm industry \\
\hline INDUS & $\begin{array}{l}\text { Set of } 14 \text { industry dummies according to the firm's main business activity (2 digit level } \\
\text { of NACE) }\end{array}$ \\
\hline
\end{tabular}


$\underline{\text { Table 2: Descriptive statistics }}$

\begin{tabular}{|c|c|c|c|c|c|c|c|c|c|c|}
\hline \multirow[t]{2}{*}{$\begin{array}{r}\text { Population } \\
\mathrm{N}\end{array}$} & \multicolumn{2}{|c|}{$\begin{array}{l}\text { All } \\
890\end{array}$} & \multirow{2}{*}{\multicolumn{2}{|c|}{$\begin{array}{c}\text { INNO=0 } \\
256\end{array}$}} & \multicolumn{2}{|c|}{$\begin{array}{c}\text { INNO=1 } \\
634\end{array}$} & \multicolumn{2}{|c|}{$\begin{array}{c}\text { R\&DYES=0 } \\
117\end{array}$} & \multicolumn{2}{|c|}{$\begin{array}{c}\text { R\&DYES=1 } \\
517\end{array}$} \\
\hline & Mean & Std. & & & Mean & Std. & Mean & Std. & Mean & Std. \\
\hline$\overline{\text { R\&DYES }^{\circ}}$ & 0.58 & 0.49 & & & 0.82 & 0.39 & & & 1.00 & 0.00 \\
\hline R\&DI & 3.02 & 2.80 & & & 4.24 & 2.42 & & & 5.20 & 1.49 \\
\hline Product Innovation ${ }^{\circ}$ & 0.65 & 0.48 & & & 0.91 & 0.28 & 0.71 & 0.46 & 0.96 & 0.20 \\
\hline Process Innovation $^{\circ}$ & 0.54 & 0.50 & & & 0.76 & 0.43 & 0.69 & 0.46 & 0.77 & 0.42 \\
\hline Business group $^{\circ}$ & 0.23 & 0.42 & 0.19 & 0.39 & 0.24 & 0.43 & 0.16 & 0.37 & 0.26 & 0.44 \\
\hline Clients $^{\circ}$ & 0.56 & 0.50 & 0.53 & 0.50 & 0.57 & 0.50 & 0.47 & 0.50 & 0.59 & 0.49 \\
\hline Competitors $^{\circ}$ & 0.36 & 0.48 & 0.41 & 0.49 & 0.33 & 0.47 & 0.31 & 0.46 & 0.34 & 0.47 \\
\hline Suppliers $^{\circ}$ & 0.24 & 0.43 & 0.29 & 0.45 & 0.22 & 0.41 & 0.24 & 0.43 & 0.21 & 0.41 \\
\hline Universities $^{\circ}$ & 0.21 & 0.40 & 0.16 & 0.36 & 0.23 & 0.42 & 0.10 & 0.30 & 0.25 & 0.44 \\
\hline Consultants $^{\circ}$ & 0.06 & 0.23 & 0.07 & 0.26 & 0.05 & 0.22 & 0.03 & 0.18 & 0.06 & 0.23 \\
\hline Business group censored & 0.17 & 0.38 & 0 & 0 & 0.24 & 0.43 & 0.16 & 0.37 & 0.26 & 0.44 \\
\hline Clients Censored $^{\circ}$ & 0.41 & 0.49 & 0 & 0 & 0.57 & 0.50 & 0.47 & 0.50 & 0.59 & 0.49 \\
\hline Competitors Censored $^{\circ}$ & 0.24 & 0.43 & 0 & 0 & 0.33 & 0.47 & 0.31 & 0.46 & 0.34 & 0.47 \\
\hline Suppliers Censored $^{\circ}$ & 0.16 & 0.36 & 0 & 0 & 0.22 & 0.41 & 0.24 & 0.43 & 0.21 & 0.41 \\
\hline Universities Censored $^{\circ}$ & 0.16 & 0.37 & 0 & 0 & 0.23 & 0.42 & 0.10 & 0.30 & 0.25 & 0.44 \\
\hline Consultants Censored $^{\circ}$ & 0.04 & 0.19 & 0 & 0 & 0.05 & 0.22 & 0.03 & 0.18 & 0.06 & 0.23 \\
\hline $\mathrm{R} \& \mathrm{D}$ cooperation $^{\circ}$ & 0.19 & 0.39 & & & 0.26 & 0.44 & 0.02 & 0.13 & 0.32 & 0.47 \\
\hline Appropriation efficiency ${ }^{\circ}$ & 0.11 & 0.31 & 0.07 & 0.26 & 0.12 & 0.33 & 0.03 & 0.16 & 0.15 & 0.35 \\
\hline Size & 4.11 & 1.32 & 3.62 & 1.15 & 4.32 & 1.33 & 3.81 & 1.25 & 4.43 & 1.32 \\
\hline Price competition $^{\circ}$ & 0.75 & 0.44 & 0.77 & 0.42 & 0.74 & 0.44 & 0.74 & 0.44 & 0.74 & 0.44 \\
\hline Non-price competition ${ }^{\circ}$ & 0.41 & 0.49 & 0.27 & 0.45 & 0.46 & 0.50 & 0.36 & 0.48 & 0.48 & 0.50 \\
\hline No. of competitors (more than 50$)^{\circ}$ & 0.17 & 0.37 & 0.21 & 0.41 & 0.15 & 0.35 & 0.24 & 0.43 & 0.13 & 0.33 \\
\hline No. of competitors (16 to 50$)^{\circ}$ & 0.12 & 0.32 & 0.12 & 0.33 & 0.12 & 0.32 & 0.13 & 0.34 & 0.11 & 0.32 \\
\hline No. of competitors (11 to 15$)^{\circ}$ & 0.46 & 0.50 & 0.43 & 0.50 & 0.47 & 0.50 & 0.43 & 0.50 & 0.49 & 0.50 \\
\hline No. of competitors (1 to 10$)^{\circ}$ & 0.25 & 0.43 & 0.22 & 0.42 & 0.26 & 0.44 & 0.20 & 0.40 & 0.27 & 0.44 \\
\hline Technological opportunities $^{\circ}$ & 0.32 & 0.47 & 0.21 & 0.41 & 0.37 & 0.48 & 0.22 & 0.42 & 0.40 & 0.49 \\
\hline Demand anticipated $^{\circ}$ & 0.32 & 0.47 & 0.24 & 0.43 & 0.35 & 0.48 & 0.25 & 0.43 & 0.38 & 0.48 \\
\hline
\end{tabular}

o Dummy variable. The period considered here is 1999-2001.

The table is similar to the one obtained for other periods (available upon request).

The $\mathrm{R} \& \mathrm{D}$ COOP variable is also considered as null for non-innovators, in order to compute

the mean of the complete sample. 
Table 3: Innovation inputs

\begin{tabular}{|c|c|c|c|c|c|c|}
\hline \multirow{4}{*}{$\begin{array}{r}\text { Column [Equation - model] } \\
\text { Model } \\
\text { Firms } \\
\text { Ext. source regressors }\end{array}$} & [1a] & [2a] & [1b] & [2b] & [1c] & [2c] \\
\hline & \multicolumn{2}{|c|}{ Heckman } & \multicolumn{2}{|c|}{ Heckman } & \multicolumn{2}{|c|}{ Heckman } \\
\hline & \multicolumn{2}{|c|}{ All } & \multicolumn{2}{|c|}{ All } & \multicolumn{2}{|c|}{$\mathrm{INNO}=1$} \\
\hline & Uncensored & Uncensored & No $\mathrm{I}$ & Uncensored & Uncensored & Uncensored \\
\hline Explained Variable & R\&DYES & R\&DI & R\&DYES & R\&DI & R\&DYES & R\&DI \\
\hline ompetitors $^{\circ}$ & $\begin{array}{c}-0,257 * * * \\
(0,073)\end{array}$ & $\begin{array}{l}-0,001 \\
(0,060)\end{array}$ & & $\begin{array}{l}-0,013 \\
(0,060)\end{array}$ & $\begin{array}{c}0,048 \\
0.098)\end{array}$ & $\begin{array}{l}-0,005 \\
(0,062)\end{array}$ \\
\hline \multirow[t]{2}{*}{ lients ${ }^{\circ}$} & $0,183^{* * *}$ & $0,102 *$ & & $0,107^{*}$ & 0,016 & 0,096 \\
\hline & $(0,068)$ & $(0,059)$ & & $(0,058)$ & $(0,092)$ & $(0,061)$ \\
\hline \multirow[t]{2}{*}{ uppliers $^{\circ}$} & $-0,137^{*}$ & $-0,053$ & & $-0,053$ & $-0,062$ & $-0,098$ \\
\hline & $(0,080)$ & $(0,066)$ & & $(0,066)$ & $(0,108)$ & $(0,070)$ \\
\hline \multirow[t]{2}{*}{ Iniversities and Colleges ${ }^{\circ}$} & $0,278 * * *$ & $0,248 * * *$ & & $0,277 * * *$ & $0,425 * * *$ & $0,254 * * *$ \\
\hline & $(0,093)$ & $(0,066)$ & & $(0,066)$ & $(0,136)$ & $(0,072)$ \\
\hline \multirow[t]{2}{*}{ onsultants ${ }^{\circ}$} & $-0,047$ & $-0,055$ & & $-0,041$ & 0,113 & $-0,026$ \\
\hline & $(0,140)$ & $(0,099)$ & & $(0,099)$ & $(0,195)$ & $(0,103)$ \\
\hline \multirow[t]{2}{*}{ usiness group ${ }^{\circ}$} & 0,025 & $-0,135^{* *}$ & & $-0,139 * *$ & 0,084 & $-0,125 *$ \\
\hline & $(0,086)$ & $(0,064)$ & & $(0,065)$ & $(0,117)$ & $(0,067)$ \\
\hline \multirow[t]{2}{*}{$\& D$ cooperation ${ }^{\circ}$} & & $0,214 * * *$ & & $0,215 * * *$ & & $0,226 * * *$ \\
\hline & & $(0,056)$ & & $(0,056)$ & & $(0,058)$ \\
\hline \multirow[t]{2}{*}{ ppropriation efficiency ${ }^{\circ}$} & $0,328 * * *$ & 0,078 & $0,319 * * *$ & 0,073 & $0,540 * * *$ & 0,092 \\
\hline & $(0,101)$ & $(0,071)$ & $(0,097)$ & $(0,071)$ & $(0,142)$ & $(0,075)$ \\
\hline \multirow[t]{2}{*}{ ize } & $0,418 * * *$ & $-0,501 * * *$ & $0,413^{* * *}$ & $-0,501 * * *$ & $0,222 * * *$ & $-0,447 * * *$ \\
\hline & $(0,029)$ & $(0,097)$ & $(0,028)$ & $(0,096)$ & $(0,036)$ & $(0,101)$ \\
\hline \multirow[t]{2}{*}{ ize squared } & & $0,047 * * *$ & & $0,046 * * *$ & & $0,042 * * *$ \\
\hline & & $(0,010)$ & & $(0,010)$ & & $(0,010)$ \\
\hline \multirow[t]{2}{*}{ rice competition ${ }^{\circ}$} & 0,025 & $-0,023$ & 0,016 & $-0,023$ & $-0,021$ & $-0,039$ \\
\hline & $(0,081)$ & $(0,064)$ & $(0,079)$ & $(0,065)$ & $(0,106)$ & $(0,066)$ \\
\hline \multirow[t]{2}{*}{ Ton-price competition ${ }^{\circ}$} & $0,220 * * *$ & 0,022 & $0,215^{* * *}$ & 0,011 & 0,087 & 0,032 \\
\hline & $(0,070)$ & $(0,056)$ & $(0,069)$ & $(0,056)$ & $(0,092)$ & $(0,059)$ \\
\hline \multirow[t]{2}{*}{ To. of competitors (16 to 50$)^{\circ}$} & $-0,132$ & $0,191^{* *}$ & $-0,136$ & $0,214^{* *}$ & $-0,074$ & $0,206^{* *}$ \\
\hline & $(0,123)$ & $(0,097)$ & $(0,121)$ & $(0,097)$ & $(0,152)$ & $(0,104)$ \\
\hline \multirow[t]{2}{*}{ To. of competitors (11 to 15$)^{\circ}$} & 0,050 & $0,136^{* *}$ & 0,054 & $0,147 * *$ & 0,094 & $0,155^{* *}$ \\
\hline & $(0,088)$ & $(0,071)$ & $(0,086)$ & $(0,071)$ & $(0,109)$ & $(0,075)$ \\
\hline \multirow[t]{2}{*}{ To. of competitors ( 1 to 10$)^{\circ}$} & 0,118 & $0,221 * * *$ & 0,129 & $0,226^{* * *}$ & $0,284^{* *}$ & $0,238 * * *$ \\
\hline & $(0,109)$ & $(0,084)$ & $(0,106)$ & $(0,084)$ & $(0,142)$ & $(0,088)$ \\
\hline \multirow[t]{2}{*}{ echno. Potential ${ }^{\circ}$} & $0,469 * * *$ & $0,128^{* *}$ & $0,482 * * *$ & $0,127^{* *}$ & $0,230 * *$ & $0,138^{* *}$ \\
\hline & $(0,078)$ & $(0,059)$ & $(0,075)$ & $(0,060)$ & $(0,101)$ & $(0,063)$ \\
\hline \multirow[t]{2}{*}{ emand ${ }^{\circ}$} & $0,423 * * *$ & $0,134^{* *}$ & $0,421 * * *$ & $0,135 * *$ & $0,256 * * *$ & $0,145^{* *}$ \\
\hline & $(0,073)$ & $(0,058)$ & $(0,072)$ & $(0,058)$ & $(0,094)$ & $(0,060)$ \\
\hline \multirow{4}{*}{$\begin{array}{l}\text { og-Likelihood } \\
\text { irm-Years } \\
\text { incensored Firm-Years? } \\
\text { irms }\end{array}$} & -43 & 78.4 & & 389.5 & -37 & 62.2 \\
\hline & & 53 & & 653 & & 103 \\
\hline & & 26 & & 826 & & 326 \\
\hline & & 44 & & 744 & & 420 \\
\hline
\end{tabular}


